\title{
母乳中のトランス酸打よび共役リノール酸含量
}

\author{
古賀 民穂*1 $・$ 月森 清己*2 $\cdot$ 中野 仁雄*2 \\ 野中美智子*3 鎌田 千束 ${ }^{* 4}$ ・菅野 道廣*4 \\ *1 中村学園大短期大学部 ( \\ *2 九州大学医学研究科生殖病態生理学 (T812-8582 福岡県福岡市東区馬出 3-1-1) \\ *3 九州大学大学院生物資源環境科学研究科 (T812-8582 福岡県福岡市東区箱崎 6-10-1) \\ *4 熊本県立大学環境共生学部（テ862-8502 熊本県熊本市月出 3-1-100）
}

\section{Trans Fatty Acid and Conjugated Linoleic Acid Content in Human Milk}

\author{
Tamiho KogA ${ }^{* 1}$, Kiyomi Tsukimori*2, Hitoo NaKano ${ }^{* 2}$, Michiko NonaKA ${ }^{* 3}$, \\ Chizuka Kamata $^{* 4}$ and Michihiro Sugano*4 \\ *1 Nakamura Gakuen Junior College \\ (5-7-1, Befu, Jyonan-ku, Fukuoka-shi, Fukuoka-ken 814-0198)
}

*2 Department of Obestetrics and Gynecology, Graduate School of Medical Science, Kyushu University

(3-1-1, Maedashi, Higashi-ku, Fukuoka-shi, Fukuoka-ken 812-8582)

*3 Division of Bioresource and Bioenvironmental Sciences, Graduate School of Kyushu University

(6-10-1, Hakozaki, Higashi-ku, Fukuoka-shi, Fukuoka-ken 812-8582)

*4 Faculty of Environmental and Symbiotic Sciences, Prefectural University of Kumamoto

(3-1-100, Tsukide, Kumamoto-shi, Kumamoto-ken 862-8502)

\begin{abstract}
Matured human milk from healthy mothers was studied for trans and conjugated fatty acid (CLA) and prostaglandin $E_{2}$ content. Average fat content was $2.74 \mathrm{~g} / 100 \mathrm{ml}$, somewhat less than that reported for milk in Japanese mothers. Cholesterol and phospholipids showed essentially average values. In total fatty acids, trans acid was $1.18 \%$ on the average ( 0.61 to $2.22 \%$ ), which is slightly less than for Western countries. The content of trans acid was unrelated to that of $\mathrm{PGE}_{2}$. CLA was approximately $0.3 \%$ of total fatty acids, but varied marked from 0.1 to $0.7 \%$. Raw cows milk contained $0.3 \%$ total fatty acids as CLA (about 12 $\mathrm{mg} / \mathrm{g}$ fat) and the particular strain of cow and time of milking appeared determinating factors. Values for city milk was comparable to those of raw milk.
\end{abstract}

Key words : human milk, trans-fatty acid, conjugated linoleic acid, prostaglandin $\mathrm{E}_{2}$

\section{1 緒言}

母乳中のトランス型不飽和脂肪酸（トランス酸）含量 については, トランス酸の多価不飽和脂肪酸代謝への影 響を考慮して，諸外国でいくつかの報告がなされてい る1),2)。わが国における母乳中のトランス酸量について は, 米久保らが赤外線吸収スペクトル法による測定で, 脂質中 4 〜 $6 \%$ 含まれると報告している ${ }^{3)}$ 。また，炭原 らは 3 人の母親の初乳, 移行乳および成熟乳のトランス

連絡者：古賀民穗
酸をキャピラリーガスクロマトグラフィーで測定し，そ れぞれ $1.7,1.4$ および $1.6 \%$ と報告し，米久保らに比 べて低值であったとしている ${ }^{4)}$ 。当然のことながら, 母 乳中のトランス酸含量は授乳婦のトランス酸摃取量に依 存しているので1),2), 日本人では欧米の值より低值を示 す。なお，一般に赤外線スペクトル法ではトランス酸值 は高值を与える傾向がある5)。

一方，トランス酸と同様に食事に由来する脂肪酸とし て共役リノール酸（CLA）がある。この脂肪酸は, 反 勿動物由来のものが主であるが，日本人の摂取量につい てはこれまで知られていない。欧米では牛乳および人乳 
中の CLA 含量については多くの報告がある ${ }^{6) ~ 8) ~}$

著者らは母乳を取得する機会があったので，母乳のト ランス酸およびCLA 含量ならびにプロスタグランジン 濃度について測定し，基礎情報を求めた。なお，いくつ かの牛乳試料についても CLA 含量を測定した。

\section{2 試料および実験方法}

\section{$2 \cdot 1$ 供 試 乳}

九州大学医学研究科生殖病態生理学に打いて得られ た，健康な母親 21 名（21～35 歳，平均年齢 29.1 歳） の成熟乳 (分婏 25〜31 日後) を試料として用いた。また， 九州東海大学農学部㧍よび熊本県畜産研究所から提供さ れた生乳 (平成 9 年 12 月, ホルスタイン, ガンジーお よびジャージー種) ならびに普通牛乳についても分析し た。

\section{$2 \cdot 2$ 脂質の抽出および脂質成分の測定}

母乳，牛乳とも Folch らの方法 ${ }^{9}$ で抽出した脂質につ いて, 総脂質は重量法, トリグリセリドはアセチルアセ トン法 ${ }^{10)}$ ，リン脂質は Gomori 法11)，コレステロールは Sperry \& Webb 法 ${ }^{12)}$ で測定した。なお，牛乳について はゲルベル法で脂肪率を測定した。

\section{$2 \cdot 3$ 脂肪酸組成の測定}

脂肪酸は母乳, 牛乳からの抽出脂質を 3 フッ化ホウ素 メタノール溶液でメチル化し，島津 GC-8 A 型ガスクロ マトグラフを用い, CP-Sil $88(0.25 \mathrm{~mm} \times 50 \mathrm{~m})$ カラ ムで, カラム温度は $180 \sim 220^{\circ} \mathrm{C}$ (昇温速度 $10^{\circ} \mathrm{C} /$ 分) の条件で分析した。CLAの分析には，島津 GC-17 A ガ スクロマトグラフを用い，Supelcowax-10 (0.32 mm X

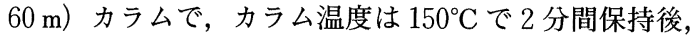
$4^{\circ} \mathrm{C} /$ 分の条件で $220^{\circ} \mathrm{C}$ まで昇温して分析した。両ガス クロマトグラフィーの分析データに基づいて CLA 含量 を算出した。すなわち，脂肪酸組成を $\mathrm{CP}-\mathrm{Sil} 88$ カラ ムで得られたチャートから求め, CLA 含量はこのカラ ムでのリノール酸 \% 值と Supelcowax-10 カラムのリ ノール酸と CLA の合計 \% 值を同じとして求めた。

$2 \cdot 4$ プロスタグランジンの測定

母乳の $\mathrm{PGE}_{2}$ 濃度は市販のキット（NEK-020, NEN Research Products, Boston, MA) を用い, ラジオイム ノアッセイ法で測定した。

\section{3 結果および考察}

\section{$3 \cdot 1$ 母乳の脂肪量および脂質組成について}

分析結果は Table 1 にまとめている。母乳の脂肪含量 は平均 $2.74(1.7 \sim 4.4) \mathrm{g} / 100 \mathrm{ml}$ で, 日本人の平均值 である $3.5 \mathrm{~g} / 100 \mathrm{ml}^{13)}$ よりいくらか低かった。トリグリ セリドは総脂質の約 $98 \%$ を占めた。コレステロールは 平均 $14.9 \mathrm{mg} / 100 \mathrm{ml}$ で，井戸田ら ${ }^{14)}$ の值と近似し，平 均的な值であった。リン脂質は平均 $17.8 \mathrm{mg} / 100 \mathrm{ml}$ で,
Table 1 Lipids Contents of Human Milk.

\begin{tabular}{|c|c|c|c|c|}
\hline \multicolumn{2}{|c|}{ No.Chol $(\mathrm{mg} / 100 \mathrm{ml})$} & \multirow{2}{*}{$\frac{\mathrm{PL}(\mathrm{mg} / 100 \mathrm{ml})}{13.3}$} & \multirow{2}{*}{$\frac{\mathrm{TG}(\mathrm{g} / 100 \mathrm{ml})}{2.25}$} & \multirow{2}{*}{$\frac{\mathrm{TL}(\mathrm{g} / 100 \mathrm{ml})}{2.3}$} \\
\hline 1 & 12.9 & & & \\
\hline 2 & 16.2 & 17.6 & 3.03 & 3.1 \\
\hline 3 & 18.6 & 18.0 & 3.62 & 3.7 \\
\hline 4 & 13.2 & 19.1 & 1.85 & 1.9 \\
\hline 5 & 12.2 & 18.0 & 1.96 & 2.0 \\
\hline 6 & 13.4 & 16.1 & 2.94 & 3.0 \\
\hline 7 & 13.1 & 13.2 & 2.63 & 2.7 \\
\hline 8 & 15.6 & 18.0 & 2.15 & 2.2 \\
\hline 9 & 16.0 & 13.6 & 3.63 & 3.7 \\
\hline 10 & 16.0 & 17.1 & 2.84 & 2.9 \\
\hline 11 & 16.2 & 19.6 & 3.14 & 3.2 \\
\hline 12 & 15.6 & 16.9 & 1.65 & 1.7 \\
\hline 13 & 13.3 & 14.6 & 1.85 & 1.9 \\
\hline 14 & 15.6 & 17.8 & 3.23 & 3.3 \\
\hline 15 & 14.1 & 18.6 & 2.55 & 2.6 \\
\hline 16 & 14.5 & 19.6 & 2.16 & 2.2 \\
\hline 17 & 13.0 & 18.7 & 2.94 & 3.0 \\
\hline 18 & 15.7 & 21.1 & 4.30 & 4.4 \\
\hline 19 & 15.5 & 21.2 & 2.94 & 3.0 \\
\hline 20 & 15.2 & 21.2 & 2.16 & 2.2 \\
\hline 21 & 17.9 & 21.4 & 2.55 & 2.6 \\
\hline Average & 14.9 & 17.8 & 2.68 & 2.7 \\
\hline SD & 1.70 & 2.50 & 0.68 & 0.7 \\
\hline
\end{tabular}

やや低い傾向にあった。

\section{$3 \cdot 2$ 母乳の脂肪酸組成およびトランス酸量}

脂肪酸組成をTable 2 に示した。組成は多くの報 告4),133,15) と類似して打り，量的に多いのはへキサデカン 酸 $(16: 0)$ ，オクタデセン酸 $(18: 1)$ 打よびオクタデ カジエン酸 $(18: 2)$ であった。トランス酸は $t-18: 1$ が主で，平均 $1.18 \%\left(0.61\right.$ 2.22\%) で，炭原ら ${ }^{4)}$ の測 定值 $1.6 \%$ より低かった。母乳中のトランス酸は $t-18$ $: 1$ 脂肪酸がほとんどであるが，母乳のこの脂肪酸につ いて，Wolff ら ${ }^{16)}$ はこれまで報告された值を検討し，多 くは正確ではなく，極性キャピラリーカラムを用いたガ スクロマトグラフィーで得られた值は 25 40\% 低い值 を与えるとし，銀イオン薄層クロマトグラフィーとキャ ピラリーGLC を組み合わせることによってより正確に $t-18: 1$ を定量することが出来ると述べている。この方 法を適用した分析で，Wollf ${ }^{17}$ および Chardigny ${ }^{18}$ はフラ ンス人の母乳中の $t-18: 1$ は総脂肪酸あたり平均 1.99\%であるとしている。一方, Chen ら ${ }^{19}$ はカナダで は $6.6 \%$ であったと報告している。今回の $t-18: 1$ の值 はいままでのわが国での報告值勇,4)のなかで最も低いも のであった。 $t-18: 1$ の分析がキャピラリーカラムのみ 


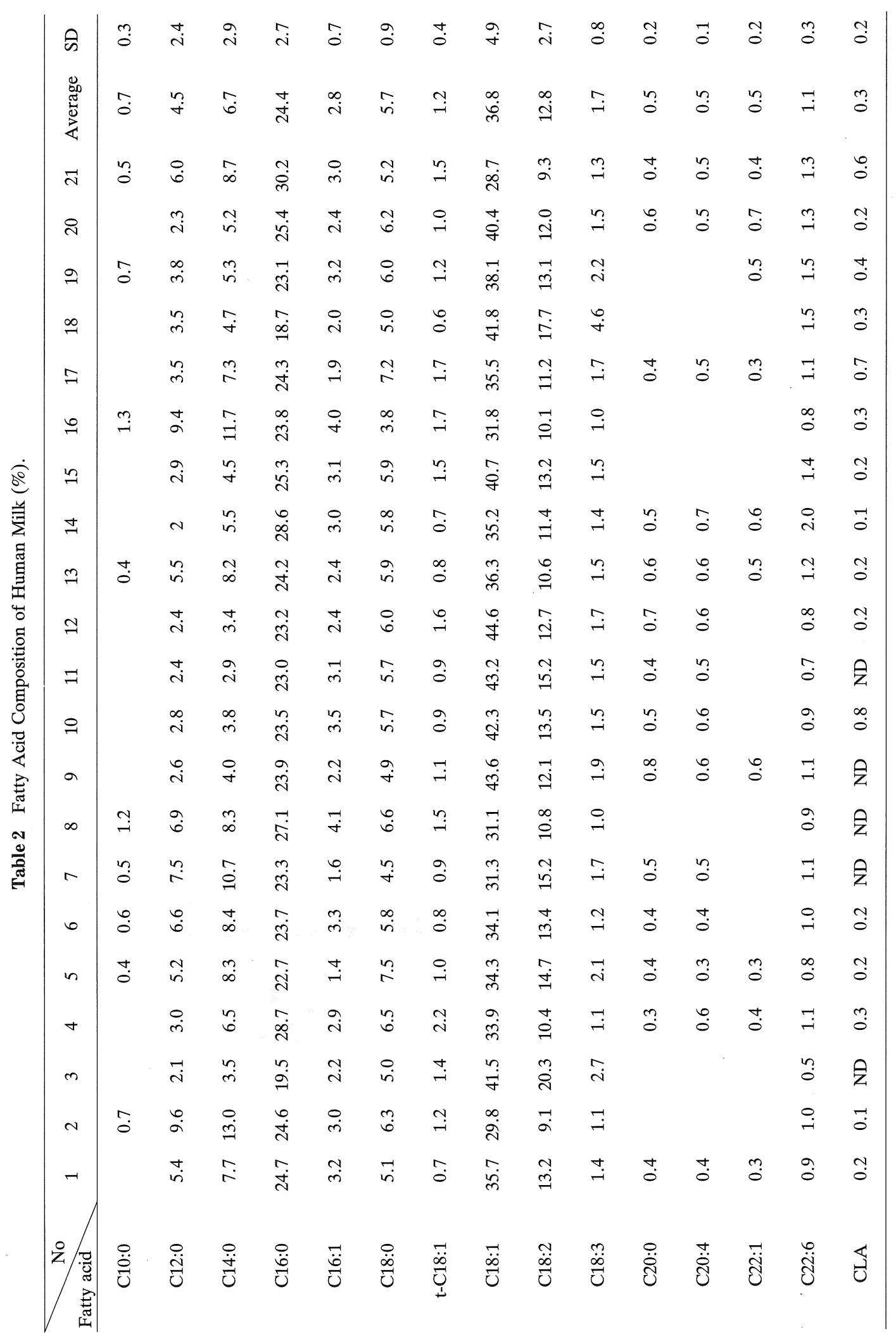


によるものであったことが関連する可能性は否定できな いかも知れないが，母乳中のトランス酸含量が撕取する

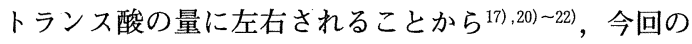
母乳提供者はトランス酸掑取量が少なかったことが十分 考えられる。事実, ナイジェリア，スペインおよびスー ダンのキャピラリーカラムで測定した值より高いもので あった ${ }^{16)}$ 。カナダ人での值に比べると大変低かったが, これはトランス酸摂取量を反映しているものであろう。 日本人の 1 人 1 日当たりのトランス酸摂取量は $1.8 \mathrm{~g}$ 程

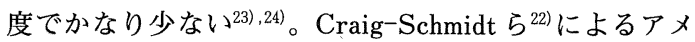
リカ人母乳中のトランス酸含量 $(\%) （ \mathrm{y})$ と泌乳前日の トランス酸掑取量. $(\%)(\mathrm{x})$ との間の関係式, $\mathrm{y}=1.49$ $+0.42 \mathrm{x}$ からみても, 総脂肪酸中で $1.49 \%$ 以上のトラ ンス酸を掑取していることが前提となっている。今回の 分析でこの関係式が適用できる例は，21 試料中 6 試料 に過ぎす；最大値を示した例 (2.22\%) でもトランス酸 掑取量の計算値は $1.7 \mathrm{~g}$ であった。

\section{$3 \cdot 3$ 母乳プロスタグランジン $\mathrm{E}_{2}$}

プロスタグランジン類は母乳中に見い出され, 幼児の 胃腸管の機能に関与するので25), その産生異常は幼児に 悪影響をもたらすと考えられる。Craig-Schmidt ら ${ }^{22)}$ は, 水素添加油脂摂取前後での母乳中の $\mathrm{PGF}_{2}, \mathrm{PGE}_{2}$ 濃度 に差は認めていない。今回 17 名の母乳の $\mathrm{PGE}_{2}$ 濃度を 測定したところ，平均 $279 \mathrm{pg} / \mathrm{ml}$ であった (Table 3)。 乳幼児においてトランス酸の摂取は血清リン脂質中のア ラキドン酸レベルを低下させる可能性が示唆されている ので1),2) $, t-18: 1$ とアラキドン酸打よびプロスタグラン ジン $\mathrm{E}_{2}$ との相関を検討したが，有意な相関は認められ なかっだ (Fig. 1)。

\section{$3 \cdot 4$ 母乳および牛乳の共役リノール酸含量}

Table 2 に示すように，母乳の総脂肪酸中に占める CLA の割合は平均で $0.3 \%$ であったが，個人差 $(0.1$ 0.8\%）が非常に大きかった。アメリカ人の母乳では CLA 含量は, $3.5 \mathrm{mg} /$ 脂肪 $\mathrm{g}$ との報告がある ${ }^{26)}$ 。同じ単

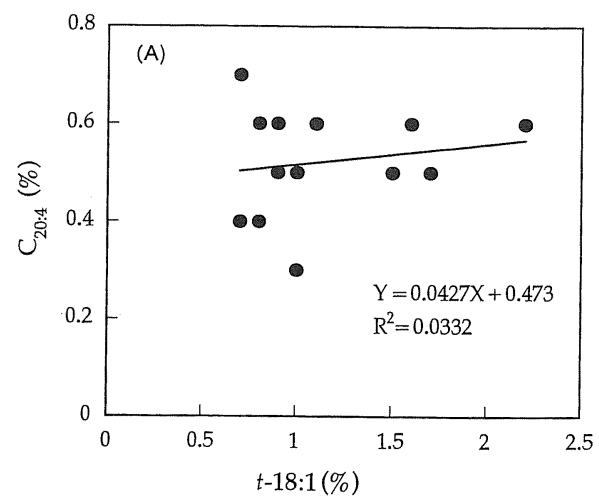

Table 3 Prostaglandin $\mathrm{E}_{2}$ Content of Human Milk.

\begin{tabular}{cc}
\hline No. & PGE $_{2}(\mathrm{pg} / \mathrm{ml})$ \\
\hline 1 & 296 \\
2 & 278 \\
3 & 316 \\
4 & 302 \\
5 & 313 \\
6 & 365 \\
7 & 382 \\
8 & 266 \\
9 & 324 \\
10 & 204 \\
11 & 202 \\
12 & 234 \\
13 & 365 \\
14 & 346 \\
15 & 121 \\
16 & 186 \\
17 & 244 \\
Average & 279 \\
SD & 72 \\
\hline
\end{tabular}

位で表わすと, 今回の結果は約 $7 \mathrm{mg} /$ 脂肪 $\mathrm{g}$ と計算され， ほぼ対比できる值であった。なお，CLAの主成分は 9 $c / 11 t^{-}$あるいは $9 t / 11 c^{-}$異性体で, $10 c / 12 t^{-}$あるいは $10 t / 12 c^{-}$がこれに次いだ。母乳の CLA 含量とトラン 覀含量との間にも有意な相関は認められなかった。一 方, 牛乳 (生乳) 中の総脂肪酸あたりの CLA 含量は乳 牛種によりいくらか差はあるものの，ほぼ $0.3 〜 0.4 \%$ 程度であった（Table 4$)$ 。普通牛乳では $0.3 \%$ 以下であ り，この值は，脂肪当たりの量に換算すると $10 \mathrm{mg} /$ 脂

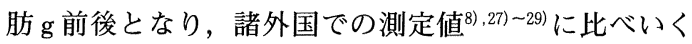
らか高いレベルであった。牛乳中の CLA 含量は飼料の 種類に影響されることが知られている29)。なお,ガンジー

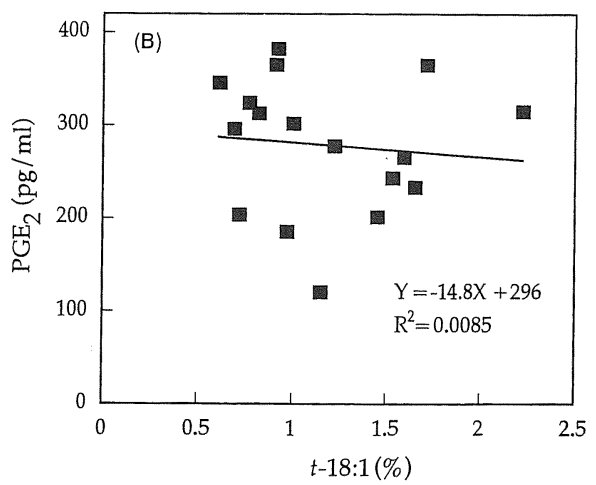

Fig. 1 Correlation between $t-18: 1$ and Arachidonic Acid Content (A) and between $t-18: 1$ and Prostagladin $\mathrm{E}_{2}$ content (B). 
Table 4 Conjugated Linoleic Acid Content of Cow's Milk.

\begin{tabular}{cc}
\hline Cow's milk & CLA (\% of total fatty acids) \\
\hline Holstein (4) & $0.33 \pm 0.05$ \\
Guernsey (4) & $0.42 \pm 0.10$ \\
Jersey (6) & $0.33 \pm 0.02$ \\
City milk (4) & $0.29 \pm 0.02$
\end{tabular}

種だけではあるが，CLA 含量は朝集乳（平均 $0.47 \%$ ) で夕集乳 $(0.33 \%)$ よりいくらか高い傾向が見られた。 普通牛乳については平均 $0.29 \%$ であり, 生乳と同じレ ベルであった。

\section{4 総括}

健康な母親 21 名の成熟乳の脂質，トランス酸および 共役リノール酸の含量, ならびにプロスタグランジン濃 度を測定した。総脂質量は平均 $2.74(1.7 \sim 4.4) \mathrm{g} / 100$ $\mathrm{ml}$ で，日本人母乳の平均值よりかなり低かったが，コ レステロールおよびリン脂質含量は平均的であった。総 脂肪酸中でのトランス酸の割合は $1.18 \%(0.64$ $2.22 \%)$ で，1985 年の報告值 $(1.6 \%)$ より低く, かつ, 欧米での測定值よりかなり低值であった。プロスタグラ ンジン $\mathrm{E}_{2}$ 濃度とトランス酸含量との間に相関は認めら れなかった。共役リノール酸の含量は総脂肪酸中平均 $0.3 \%$ であったが，個人差が大きかった（0.1〜0.8\%）。 生乳の共役リノール酸含量は乳牛の種類, 搾乳時間など により影響されるようであったが，平均して $0.3 \%$ 前後 であった(約 $12 \mathrm{mg} / \mathrm{g}$ 脂肪)。普通牛乳でも同等であった。

$$
\text { 謝辞 }
$$

母乳を提供された方々ならびに生乳を提供された東海 大学農学部および熊本県畜産試験場に深謝する。

（受付：1999 年 8 月 13 日, 受理：1999 年 11 月 11 日)

$$
\text { 文献 }
$$

1) B. Koletzko, Acta Paediatr. 81, 302 (1992).

2) B. Koletzko, Eur. J. Med. Res. 1, 123 (1995).

3) 米久保明得, 山本良郎, 飯田耕司, 高橋 新, 土 屋文安，小児保健研究，40, 547 (1981).

4) 炭原加代, 橋本 皓, 大阪府立看護短大紀要, 7, 65 (1985).

5) 岡本隆久, 堤 崇史, 東海林 茂, 荏原 紘, 丸 山武紀, 新谷 勛, 菅野道廣, 日本油化学会誌, 投稿中

6) H. Lin, T.D. Boylston, M.J. Chang, L.D.
Leudecke, T.D. Shulz, J. Dairy Sci., 78, 2358 (1995).

7) A.C. Fogerty, G.L. Ford, D. Svoronos, Nutr. Rep. Int. 38, 937 (1988).

8) M.K. McGuire, Y. Park, R.A. Behre, R.N. Ibclc, Y.L. Harrison, T.D. Shultz, M.A. McGuire, Nutr. Res., 17. 1277 (1997).

9) J. Folch, M. Lees, G.H. Sloane-Stanley, J. Biol. Chem., 226, 497 (1957).

10) M.J.A. Fletcher, Clin. Chim. Acta, 22, 393 (1968).

11) G. Gomori, J. Lab. Clin. Med., 27, 955 (1942).

12) W.M. Sperry, M. Webb, J. Biol. Chem., 187, 97 (1950).

13）科学技術庁資源調查会編，四訂日本標準成分表， 医柬薬出版 (株), (1998).

14）井戸田 正，桜井稔夫，菅原牧裕，松岡康浩，石 山由美子，村上雄二，森口宏康，竹内政弘，下田 幸三, 浅居良輝, 日本小児栄養消化器病学会雑誌, 5, 159 (1991).

15）八尋政利, 村上雄二, 皆川憲夫, 阿部建吉, 栄食誌, 41, 263 (1988).

16) R.L. Wolff, D. Precht, J. Molkentin, J. Am. Oil Chem. Soc., 75, 661 (1998).

17) R.L. Wolff, J. Am. Oil Chem. Soc., 72, 259 (1995).

18) J.M. Chardigny, R.L. Wolff, E. Marger, J.L. Sebedio, L. Martine, P. Juaneda, Eur. J. Clin. Nutr., 49, 523 (1995).

19) Z.-Y. Chen, G. Pelletier, R. Hollywood, W.M.N. Ratnayake, Lipids, 30, 15 (1995).

20) H.P. Kaufmann, E. Volbert, G. Mankel, Fette Seifen Anstichm, 63, 261 (1961).

21) J.M. Aitchison, W.L. Dunkley, N.L. Canolty, L.M. Smith, Am. J. Clin. Nutr., 30, 2006 (1977).

22) M.C. Craig-Schmidt, J.D. Weete, S.A. Faircloth, M.A. Wickwire, E.J. Livant, Am. J. Clin. Nutr., 39, 778 (1984).

23）古賀民穂，竹内知代，菅野道廣，栄食誌， 50, 180 (1997).

24）岡本隆久，木下葉子，兼松 弘，新谷 勋，菅野 道廣, 油化学, 42, 996 (1993).

25) B. Reid, H. Smith, Z. Friedman, Pediatrics, 66, 870 (1980).

26) S.F. Chin, W. Liu, J.M. Storkson, Y.L. Ha, M.W. Pariza, J. Fd. Composition Anal., 5, 185 (1992).

27) J. Jiang, L. Bjorck, R. Fonden, Int. Dairy J., 7, 863 (1997).

28) J. Fritsche, H. Steinhart, Z. Lebensm, Unters. Forsch. A., 206, 77 (1998).

29) J. Jiang, L. Bjoerck, R. Fonden, M.E. Emanuelson, J. Dairy Sci., 79, 438 (1996). 


\title{
[報文］ ホスホリパーゼ $\mathrm{A}_{2}$ による大豆ホスファチ ジルコリンの加水分解
}

\author{
山下政続 ・ 足立秀哉 ・ 徳力尚美 \\ 太陽化学 (株) 総合研究所（广 510-0844 三重県四日市市宝町 1-3）
}

ホスフォリパーゼ $\mathrm{A}_{2}$ を用いた大豆ホスファチジルコリン（S-PC）のリゾホスファチジルコリンへの静置加水 分解反応を, 種々の条件下で検討した。加水分解率は, 高速液体クロマトグラフ法 (HPLC) で, ホスファチジ ルコリン（PC）とリゾホスファチジルコリン（LPC）を分析して求めた。この HPLC 法は, S-PCの加水分解に おいて PC と LPC を分析するのに簡単で迅速に行える再現性のある方法であった。 S-PCの加水分解率は, 反応 温度, 反応時間, $\mathrm{CaCl}_{2}$ 濃度, 緩衝液の種類に依存した。 S-PC は, Tris- 塩酸緩衝液の方が $\mathrm{H}_{3} \mathrm{BO}_{3}-\mathrm{KCl}-\mathrm{NaOH}$ 緩衝液, $\mathrm{NaH}_{2} \mathrm{PO}_{4}-\mathrm{Na}_{2} \mathrm{HPO}_{4}$ 緩衝液, $\mathrm{Na}_{2} \mathrm{HPO}_{4}$-クエン酸緩衝液よりも簡単に加水分解を受けた。ホスフォリパー ゼ $\mathrm{A}_{2}$ による S-PCの最適加水分解条件は, Tris-塩酸緩衝液； $\mathrm{pH} 8, \mathrm{CaCl}_{2} ; 0.3 \mathrm{wt} \% / \mathrm{S}-\mathrm{PC}, .60^{\circ} \mathrm{C}, \mathrm{S}-\mathrm{PC} /$ 水溶液；1/2 ( $/ \mathrm{mL})$ ，ホスファリパーゼ $\mathrm{A}_{2} ; 101 \mathrm{U}$ であった。

(連絡者：山下政続） Vol.49, No.2, $151 （ 2000 ）$

\section{[報文］母乳中のトランス酸および共役リノール酸含量}

古賀民穂*1 ・ 月森清已事 ・ 中野仁雄*2

野中美智子苂。鎌田千束 ${ }^{* 4}$ 。菅野道廣*4

*1 中村学園大短期大学部 （T 814-0198 福岡県福岡市城南区別府 5-7-1）

*2 九州大学医学研究科生殖病態生理学 (T 812-8582 福岡県福岡市東区馬出 3-1-1)

*3 九州大学大学院生物資源環境科学研究科 (T 812-8582 福岡県福岡市東区箱崎 6-10-1)

$* 4$ 熊本県立大学環境共生学部 （T 862-8502 熊本県熊本市月出 3-1-100）

健康な母親 21 名の成熟乳の脂質，トランス酸含量および共役リノール酸ならびにプロスタグランジン濃度を 測定した。総脂肪量は平均 $2.74 （ 1.7 \sim 4.4 ） \mathrm{~g} / 100 \mathrm{ml}$ で, 日本人母乳の平均值よりかなり低かったが，コレス テロールおよびリン脂質含量は平均的であった。総脂肪酸中でのトランス酸の割合は $1.18 \%(0.61 \sim 2.22 \%)$ で, 1985 年の報告值 $(1.6 \%)$ より低かった。この值は欧米での測定值よりかなり低值であった。プロスタグランジ ン $\mathrm{E}_{2}$ 濃度とトランス酸含量との間に相関は認められなかった。共役リノール酸の含量は総脂肪酸中平均 $0.3 \%$ あったが, 個人差が大きかった $(0.1 \sim 0.8 \%)$ 。生乳の共役リノール酸含量は乳牛の種類，搾乳時間などにより 影響されるようであったが，平均して $0.3 \%$ 前後であった（約 $12 \mathrm{mg} / \mathrm{g}$ 脂肪）。普通牛乳でも同等であった。

（連絡者：古賀民穂） Vol.49， No.2，157（2000） 